$$
r \circ \mathbb{Z} h \odot v \circ r
$$





\section{Na malém literárním poli má kritika enormní význam}

Knihu Dějiny finskošvédské literatury v perspektivě bourdieuovské sociologie, nad níž jsme vedli rozhovor s jejím autorem, odborníkem na finskou literaturu Janem Dlaskem, s tématem tohoto čísla pojí nejen metodologické zakotvení v literární sociologii Pierra Bourdieua, ale též perspektiva „malé literatury“, kterou finskošvédské literární pole v mnohém připomíná historickou situaci v českých zemích. Rozhovor se tak mj. stočil též na specifika literárního pole menšinové literatury, jakou finskošvédská literatura je, a na úlohu literárního kritika v takovémto poli. Došlo však i na podněty, které výzkum finskošvédské literatury nabízí pro popis nejen literárního pole českého, ale i českoněmeckého. Pozice finskošvédského literárního pole mezi polem říšskošvédským a finskojazyčným, prolínání těchto polí i fenomén odchodů finskošvédských spisovatelů a kritiků do Švédska - všechny tyto postřehy, k nimž se nabízejí strukturní protějšky při popisu českoněmeckého písemnictví, lze jistě podnětně aplikovat též na areálově a transkulturně zaměřený výzkum dějin literatur na území českých zemí.

Váš zájem o téma finskošvédské literatury je dlouhodobý a jistě předchází setkání s literární sociologií Pierra Bourdieua. Vybavíte si ještě moment, kdy Vás napadlo aplikovat ji na oblast svého zájmu? Vjakých souvislostech jste začal uvažovat o napsání jejích dějin $v$ sociologickém rámci?

K onomu momentu došlo v souvislosti s mou disertační prací na téma „Debata Tikkanen - Kihlman“. Šlo o příběh dvou autorů, kteří pocházeli z tzv. „dobrých finskošvédských rodin“, a příběh jejich rozštěpené recepce. Zatímco v 60. letech 20. století čtenářstvo tleskalo vášnivým výpovědím autorů, kritizujícím milieu jejich původu, v následujícím desetiletí už jeho část měla zájem číst také díla z poněkud méně sociálně náročných prostředí střední třídy, dělnictva, sedláků či rybářů, která byla pro finské Švédy vlastně sociologicky reprezentativnější než prostředí Tikkanenovo a Kihlmanovo. Měl jsem možnost navazovat na licenciátní práci Trygveho Söderlinga, jenž analyzoval jinou finskošvédskou literární polemiku, o deset let starší debatu o modernismu z poloviny 60. let. Söderlingův přístup spočíval jednak v nalezení určitých tematických linií modernistické 
debaty (v první části jeho studie), jednak v hledání kořenů sporů mezi jejími jednotlivými aktéry v historii jejich předchozích vzájemných rozmíšek (v druhé části studie), jednak v pokusu o interpretaci debaty o modernismu „bourdieuovsky“ (v části třetí). Právě tato Söderlingova analýza finskošvédského literárního pole $\mathrm{v}$ době kolem roku $1965 \mathrm{z}$ třetí části pro mě byla při určitých komplikacích při psaní mé disertační práce východiskem $k$ tomu, aby se mi ve změti obsáhlého primárního materiálu podařilo nalézt „červené linie“; jinými slovy, formulovat to, jak se finskošvédské literární pole stačilo za dobu let 1965-1975 proměnit a jak se $\mathrm{k}$ této proměně pak vztahovala mnou zkoumaná debata. O napsání „celoplošných“ finskošvédských literárněsociologických bourdieuovských dějin jsem začal uvažovat na konferenci NORLIT v Roskilde v roce 2011 při příspěvku Kristiny Malmio o sporech finskošvédských básníků Jarla Hemmera a Elmera Diktonia z 20. let 20. století. Napadlo mě k tématu přistupovat znovu bourdieuovsky, a odtud byl pouze krok k úvaze o možném pokusu zmapovat celé finskošvédské literární pole od dob jeho vzniku až po současnost.

Váš př́stup k tématu dějin finskošvédské literatury je charakteristický zaměřením jednak na príchod aktérů jednotlivých generací na literární pole vyznačující se svými polaritami, jednak na jejich osvojování pravidel fungování pole, literárnich žánrů, stylů či způsobu psaní, je pochopitelné vzhledem k záměru poskytnout čtenářưm současně přehled látky, jak jej podávají tradičně pojaté historiografické přiručky. Uvažoval jste však o možném širším uplatnění i jiných kognitivních nástrojů bourdieuovské sociologie, např́klad konceptu habitu ve vztahu k rozdílnosti venkovského a městského prostředí? Měly by různé odlišné akcenty šanci dospět rovněž k syntetičtějšímu obrazu literárních dějin, nebo jsou podle Vás vhodné spiše pro analýzu dílčích otázek?

Rozdílnost venkovského a městského prostředí je u finských Švédů velmi důležitou záležitostí a ve své studii na ni rovněž narážím, i když tam není úplně tou meritorní. K syntetičtějšímu obrazu literárních dějin by jakékoliv odlišné akcenty určitě přispěly, a ucelenou studii finskošvédské literatury založenou právě na Vámi navrhovaném konceptu si umím představit. Ihned ale vyvstává otázka, jak postihnout „šedou zónu“ mezi městem a venkovem. Jak definovat příslušnost: na bázi původu či na bázi prostředí v textech? U některých autorů či jiných aktérů totiž není zařazení do jednoho z těchto prostředí naprosto samozřejmé. Někteří finskošvédští autoři původem $\mathrm{z}$ venkova $\mathrm{v}$ průběhu své dráhy částečně „změštáčtěli“, ale na druhou stranu zůstali venkovu i částečně 
věrní. A otázkou je, jestli by nebylo i produktivní dělicí linii ve Švédském Finsku koncipovat jako dichotomii mezi Helsinkami a jejich aglomerací na straně jedné a zbytkem Švédského Finska na straně druhé - ten tvoří jednak venkov, jednak ale také malá či středně velká města, v nichž určitý literární život rovněž probíhá. Možná právě fakt, že přichází hned tolik otázek, poukazuje na produktivnost navrhovaného př́stupu.

Do jaké míry je podle Vás Bourdieư̊v model literárního pole, vypracovaný striktně na podkladu francouzského milieu, adekvátně přenositelný do interkulturního, multilingválního prostředí? Mnohé $z$ Vaší práce je inspirativní např́klad pro úvahy o situaci německojazyčné literatury v českých zemích v 19. a na počátku 20. století. Ve své knize zdůrazňujete menšinovou pozici finskošvédského literárního pole mezi literárním polem ř́̌šskošvédským a finskojazyčným. Jak se tato menšinová pozice projevovala ve strategiích aktérů finskošvédského literárního pole?

Severská bourdieuovská škola shledala bourdieuovský model za potenciální i pro studium jednotlivých polí na transnacionálním základě (viz též můj komentár̆, Slovo a smysl, 20 (X) 2013). Pokud by k tomuto závěru nedošla, obávám se, že by to výrazně zmenšilo jeho potenciál, zvláště v dnešní globalizované době. Bourdieuova fixovanost na francouzské prostředí se tak v tomto smyslu stává paradoxně (již překonanou) výjimkou, která potvrzuje pravidlo. Je třeba nicméně dodat, že Bourdieua nikde nelze převádět mechanicky ani dogmaticky.

Menšinová pozice finskošvédských aktérů mezi polem řišskošvédským a finskojazyčným se v jejich strategiích projevovala na mnohý různý způsob. Na jednu stranu je $\mathrm{v}$ argumentačních přístupech finskošvédské minority přítomna strategie „oni [majority] nám nerozumí, což se projevuje i na literárním poli. Na stranu druhou, každá nová generace hledala spíše rozšíření vlastního horizontu, často právě směrem $\mathrm{k}$ ř́išským Švédům a finskojazyčným Finům, usilovala o vzájemnou spolupráci a také ji prováděla. U některých autorů se dokonce tato strategie zvrhla $\mathrm{v}$ provokativní veřejné zdůrazňování tohoto přístupu: „Mám rád říšské Švédy a finskojazyčné Finy, nemám rád finské Švédy.“ Zatímco finskojazyční literáti hledali u finských Švédů inspiraci dřive, opačným směrem $\mathrm{k}$ tomu začalo docházet až v 60 . letech 20. století.

Je nicméně pozoruhodné, že mnoho krátkodobých avantgardních finskošvédských literárních či kulturních časopisů, kterým se ve studii rovněž věnuji, bylo dvojjazyčných. Někteří z celkem výrazných finskošvédských autorů byli bilingvní, psali švédsky i finsky. To jsou všechno záležitosti, které dosavadní literární dějiny 
sice úplně nezamlčovaly, ale také nijak nezdůrazňovaly, zmiňovaly je „mimochodem".

Další fenomén spočívá $v$ tom faktu, že obě velká pole ono pole malé prostě nemohou neovlivnit i třeba pouze tím, co o finskošvédské literatuře jejich aktéři napíší. To může vyvolat na finskošvédském poli protireakce, které pak spustí určité procesy.

Můžete stručně predstavit předpoklady pro rozvinutí autonomie finskošvédského literárního pole? Ve své knize se zmiňujete napríklad o vzniku prvního spisovatelského „cechu“ $k$ roku 1864, tedy v době, kdy se v Praze rozbíhala činnost Umělecké besedy. $V$ čem spočivala specifika autonomizace finskošvédského literárního pole oproti iniciačnímu francouzskému prostředí?

Onen „cech“ vznikl ještě v době, kdy finskošvédské literární pole nebylo zvlášt od celofinského diferencované. Je zajímavé, že proces jeho autonomizace úzce souvisí se vznikem finskošvédské literatury jako takové, tak jak je datován i v tradičních literárněhistorických příručkách (tj. někdy na přelomu 19. a 20. století). Mj. až od této doby se používají pojmy „finskošvédský“/„finský Švéd“ a „Švédské Finsko“. Autonomizace pole souvisí s procesy potýkání se jednotlivých národností, to je vzhledem k Francii důležitý rozdíl. Finské velkovévodství je na přelomu století součástí carského Ruska s dvěma úředními jazyky, finštinou a švédštinou, většinové finskojazyčné obyvatelstvo ale cítí, že švédština má jako jazyk stále ještě významné části elity v zemi pořád výsostnější postavení, než by odpovídalo počtu švédskojazyčných obyvatel, a podniká kroky, aby tomu učinilo přítrž - což je ze strany Švédů ve Finsku vnímáno jako populistický finskojazyčný nacionalismus. Do toho ještě přichází do Finska z Petrohradu autoritativní rusifikační tlaky. V této situaci vstupuje na scénu skupina švédskojazyčných mladých intelektuálů, kteři se nechtějí zaplést ani s Rusy, ani s Finy, ale ani s aktivizovaným národnostním hnutím Švédů, kteří se proti všem tlakům ze strany majorit brání (i když v tomto odhodlání poté nebyli vždy úplně důslední). Jediné, s čím se ze začátku zaplést chtějí, je samotné umění; představují si, že by díla měla být hodnocena pouze a jen podle estetických kritérií (a zde již zase vidíme paralelu s Francií).

Jedná se o aktéry seskupené kolem časopisu Euterpe; ono seskupení ve své studii chápu jako první finskošvédskou literární generaci. Toto avantgardní pokolení je výrazně evropsky a kosmopolitně orientované. Je pro něj ctí být dekadentní a pobuřovat konzervativní kritiku, stále ještě čerpající z odkazu národní- 
ho romantismu. Ekonomické potíže při vydávání časopisu jsou aktéry vnímány v podstatě jako pozitivum, což už odkazuje k „obrácené ekonomii“, tj. specifické logice autonomního pole. Euterpisté se také přibližili univerzalistickému ideálu intelektuála se specifickou autoritou odvozenou od autonomní sféry, inspirovanému Francií, který analyzuje také Bourdieu. Někteří z nich v této době rovněž pěstovali čilé kontakty s Pařiží, dokonce v ní i pobývali. Mj. proces s Dreyfusem v této době podnítil také angažmá evropských intelektuálů proti carskému útlaku ve Finsku jako angažmá ve prospěch malého národa proti imperialistické velmoci, které mělo už také „zolovské rysy“. Takže paralel s Francií je rovněž mnoho, a nejen paralel - přímo inspirace $z$ ní.

Také Vaše závěry jsou leckdy srovnatelné se situací české literatury. Uvažujete např́klad o důležitější roli sociálního kapitálu, prátelských vazeb či rodinných klanů $v$ literárním životě včetně důležitého procesu kanonizace autorů. V úvodu své práce přitom vysvětlujete, že - mj. s ohledem na českého čtenáře, jemuž prostředkujete poznatky z jinojazyčných badatelských poli - v zásadè akceptujete rozvrh již existujících historiografických příruček včetně procesu kanonizace, jak jej popsaly. Bourdieu přitom přinejmenším deklaruje svoji nezávislost na kanonizačním procesu. Lze však dle Vašeho minění kanonizační proces - a to bez ohledu na to, zda badatel ve zkoumané kultuře vyrůstá, nebo ji zkoumá „zvenči“ - vůbec obejít?

Chtěl jsem rovněž napsat příručku pro zájemce o finskošvédskou literaturu jako takovou a nepřišlo mi při tom schůdné již existující historiografické př́iručky zcela pominout. Na druhou stranu doufám, že je z mé práce patrné, že místo autorů v kánonu nechápu jako samozřejmé, ale jako ustavené procesy na literárním poli, které jsem se v rámci možností, který mi rozsah studie dovoloval, pokusil nastínit. Deklarace nezávislosti na kanonizačním procesu vychází u Bourdieua z jeho estetiky a je skutečně klíčová - mnohokrát ji zdůrazňuje. V části Pravidel umění popisující autonomizaci literárního pole ve Francii v druhé polovině 19. století jsou nicméně zmiňovány dráhy autorů, které zná i gymnazista (a to někdy navíc nikoliv gymnazista francouzský, nýbrž český). Jsou to spisovatelé, kteří ke kánonu neodmyslitelně patří, a tak se nabízí otázka, proč Bourdieu do své studie vybral právě je. Jde pak o to, jestli jeho zpracování není třeba chápat spíše jako badatelský projekt k mnohem rozsáhlejší analýze, která by jeho předpoklady (vzniklé na bázi dosavadních kanonizačních procesů) mohla potvrdit či vyvrátit. Obejít kanonizační proces, zavrhnout vše, co doposud bylo o kultuře/literatuře napsáno, a vrhnout se na materiál „ad fontes“ se může 
zdát velmi bourdieuovské, ale je nutno předestřít, že takto zavržené studie $\mathrm{k}$ materiálu $\mathrm{v}$ tomto typu bádání patří $\mathrm{v}$ tom smyslu, že i ony př́slušnou pozici aktéra na poli pomáhaly ustavit. Navíc velikost badatelských týmů by v těchto případech musela být enormní. Domnívám se, že tímto zpơsobem mohou badatelé-jedinci zkoumat pouze určité výseky pole - například bud výseky časové, nebo dráhy jednotlivých aktérů; maximálně stav celého pole k jednomu jedinému momentu (blíže znovu viz Slovo a smysl, 20 (X) 2013).

Dalši podstatnou charakteristikou neobsáhlého kulturního prostoru, o které píšete $v$ závěru své práce, je časté prolínáni aktérských roli literárního kritika, autora a/ nebo literárního badatele. Tímto rysem se zejména $v$ 19. století vyznačovala i česká literatura, nemluvě o časté personální unii politika a umělce - vzpomeňme zejména mladické pokusy i takových osobností, jako byli Palacký, Rieger či Kaizl. Je podle Vás Bourdieuův model dostatečně senzitivní pro porozumění těmto zmnoženým pozicím? Narazil jste při své práci v tomto ohledu na nějaké limity Bourdieuova modelu?

Pokud vím, Bourdieu skutečně nikde explicitně nepíše o prolínání aktérských rolí, nicméně Flauberta či Zolu vnímá implicitně jak v roli spisovatelů, tak v roli aktérů veřejného dění své doby, díky které také etablovali svou pozici na literárním poli - to jsou dvě strany jedné mince. Možná, že jsem ve své studii tyto zmnožené pozice více zdůraznil, nebot̉ mi přišly jako zvláště typické pro malé finskošvédské literární pole. Jako limit Bourdieuova modelu nadnesený fakt nicméně nevnímám, spíše jej chápu jako potenciál pro jeho rozvinutí.

Závěrem bychom se rádi zeptali na úlohu literární kritiky v dějinách literatury. Bourdieu ji nikde soustavně nereflektoval, ale ve Vaší práci má tato instituce takřka klíčovou roli. Nepochybnè to souvisí s blízkostí kritiky kanonizačnímu procesu, zejména jeho počátkům. Lze se však důvodně domnivat, že úloha kritiky je v neobsáhlých literárních polích relativně vyšší než v případè velkých kultur a plně rozvinutých literárních polí?

Zde jsem zjevně pod určitým větším vlivem severské bourdieuovské školy, která literární kritice, alespoň v jedné ze studií (Donald Broady), připsala při interpretaci mechanismů na literárním poli klíčovou roli. Nicméně, ač Bourdieu skutečně přímo literární kritiku soustavně teoreticky nereflektoval, těžko si představit její nepř́tomnost v procesech, které popisuje; ta role je asi klíčovější, než sám výslovně dovozuje. Alespoň já jsem Pravidla umění takto četl. Chápu 
literární kritiku jako velmi důležitý první stupeň v kanonizaci, ihned po aktu autora a jeho nakladatele spočívajícím ve vydání díla. A skutečně soudím, že na malém finskošvédském literárním poli má kritika enormní význam. Počet tiskovin a tím tedy i publikačních fór pro literární kritiku (počet pozic) je tu výrazně omezenější, a velkou část $\mathrm{z}$ nich navíc vytváří regionální tisk (dnes již existují jen jedny „celofinskošvédské“ noviny a sem tam nějaký literární časopis) - čímž ale vlastně v porovnání s poli velkými roste význam oněch jednotlivých pozic. Alespoň na příběhu etablování finskošvédského modernismu je role kritiky vidět zcela zjevně. A znovu se zde dostáváme $\mathrm{k}$ fenoménu zdvojení rolí: byli-li modernisté zároveň i literárními kritiky, mohli velmi výrazně ovlivňovat procesy kanonizace modernismu, což také více než aktivně činili. Toto zdvojování vlastně literární pole dále „smrštuje“ (tedy když je místo autora a kritika na poli přítomen autor-kritik) - čímž opět úměrně roste vliv těch několika málo aktérů, kteří se na poli pohybují. A mají-li i roli kritiků, pak je také větší vliv jejich literárněkritické činnosti.

Děkujeme Vám za rozhovor.

Ladislav Futtera a Martin Hrdina

Mgr. Jan Dlask, Ph.D. (* 1973), vystudoval finštinu a švédštinu na Filozofické fakultě Univerzity Karlovy v Praze. Vědecky a pedagogicky pưsobí tamtéž na oddělení finských studií Ústavu germánských studií jako odborný asistent. Specializuje se na švédskojazyčnou literaturu ve Finsku, často z literárněsociologické perspektivy; jako výstup postdoktorského projektu GA ČR publikoval monografii Dějiny finskošvédské literatury v perspektivě bourdieuovské sociologie (2018). Zabýval se rovněž finskou literaturou na české literární scéně a populární literaturou. Přednáši hlavně finskou literaturu, její české překlady také recenzuje v kulturním tisku. Absolvoval několik zahraničních stáží predevším ve Finsku. Dřive také pedagogicky externě pưsobil na Univerzitě Pardubice. 
